\title{
26 Research Soure \\ Transitional Wave Climate Regions on Continental and Polar Coasts in a Warming World
}

Itxaso Odériz ( $\nabla$ itxaso.oderiz@gmail.com )

Instituto de Ingeniería, Universidad Nacional Autónoma de México https://orcid.org/0000-0002-63381141

Nobuhito Mori

Kyoto University https://orcid.org/0000-0001-9082-3235

\section{Tomoya Shimura}

Disaster Prevention Research Institute, Kyoto University

\section{Adrean Webb}

Disaster Prevention Research Institute, Kyoto University, Japan

\section{Rodolfo Silva}

Universidad Nacional Autonoma de Mexico https://orcid.org/0000-0003-0064-9558

\section{Thomas Mortlock}

Risk Frontiers and Department of Earth and Environmental Sciences, Macquarie University

\section{Article}

Keywords: Climate change, wave power, mean wave direction

Posted Date: November 3rd, 2021

DOI: https://doi.org/10.21203/rs.3.rs-885191/v1

License: (c) (i) This work is licensed under a Creative Commons Attribution 4.0 International License.

Read Full License

Version of Record: A version of this preprint was published at Nature Climate Change on June 16th, 2022. See the published version at https://doi.org/10.1038/s41558-022-01389-3. 


\section{Abstract}

We provide a comprehensive analysis of the spatial-temporal changes in the atmospheric-driven major wave climates (easterlies, southerlies, and westerlies) under two different Representative Concentration Pathways, the RCP2.6 and RCP8.5 scenarios for the end-of-the-century (2075-2099). By comparing the projected scenarios with historical conditions, we found that the easterly wave climates will be more frequents in the southwest basins (up to $15 \%$ ) and the southerlies in the eastern basins (up to $20 \%$ ). While the westerlies are projected to reduce their presence in the mid-latitudes and intensify for the high latitudes associated with the poleward extratropical circulation. As a result, coastal risk will be triggered in transitional wave climate regions, in addition to the risk induced by sea-level rise and storm wave generated, by spatial and frequency changes in the prevailing wave climates that will reach regions where up to now they have not, impacting future coastal environments.

\section{Introduction}

Coastal systems and industries that depend on wave climate are prone to be highly vulnerable to the climate crisis ${ }^{1-4}$, as more and more research reinforces the evidence that climate change is and will impact ocean waves $5,6,15,7-14$. Wave climate is well known to be a primary driver of coastal risk (erosion ${ }^{1,3}$ and flooding ${ }^{16,17}$ ), and controls the balance of mass and energy fluxes in coastal ecosystems ${ }^{18}$. From a global perspective, characteristics of coastal environments, such as the distribution of ecosystems (coral reefs ${ }^{19}$, seagrasses ${ }^{20}$, and mangroves ${ }^{21}$ ) and coastal features (carbonsoil mangroves ${ }^{22}$, sedimentary environments ${ }^{23}$ ), vary based on the major climate regions (planetary areas delimited by atmospheric circulation and similar climate conditions) that they inhabit. Indeed, not only changes in storminess but also spatial and temporal changes in climate regions (e.g., tropicalsubtropical, subtropical-extratropical, and extratropical-polar), can severely alter nearshore processes and cause substantial changes to the prevailing wave climate (e.g., significant wave height, mean wave direction). These can exceed the thresholds of natural variability and complicate efforts to adapt coastal systems to climate change.

In order to track regions of change where different wave climates will govern, analysis is needed of the spatial-temporal patterns of global wave climate. These regions, which we call here "transitional wave climate regions," will be fundamental for identifying ocean and coastal environments at risk ${ }^{24}$, and employing an Ecosystems-based approach for climate change adaptation. However, most existing wave projection studies only concentrate on analyzing mean ${ }^{5,8,11,12}$ and extreme wave $e^{7,15,25,26}$ parameters. Differences in spatial and temporal scales between the climate system and wave processes (e.g., generation, propagation, and dissipation), as well additional sources of uncertainty from gas emissions projections, wave models, and global climate models $(\mathrm{GCMs})^{8}$, hinder the predictability of coastal hazards at the planetary-scale and so the local scale. Recently, remarkable efforts have focused on developing a comprehensive wave climate framework to identify large-scale shifts in wave climate that 
are driven by atmospheric systems (planetary winds ${ }^{27-30}$ and sea level pressure systems ${ }^{31}$ ); however, transitional wave climate regions have not yet been investigated.

In this paper, we explore changes in the atmospheric-driven wave climates using a high-resolution atmospheric circulation model under two different Representative Concentration Pathways (RCP)-the RCP2.6 and RCP8.5 scenarios. Seasonal changes in the wave climates between historical and future climate conditions are examined for wave power, wave direction, and the ocean areas covered; in addition, these changes are connected with shifts in atmospheric circulation. And finally, we pay special attention to wave climate changes in coastal regions that have been identified as critical by the Special Report on the Ocean and Cryosphere in a Changing Climate (SROCC $)^{32}$, that is continental, sea-ice affected, and permafrost coastlines.

\section{Main Text}

\section{Projected changes in wave climates induced by atmospheric circulation}

In Odériz et al. $(2021)^{30}$, major wave climates are defined and explained as regions in time and space that share similar characteristics of wave power and mean wave direction. In addition, they are generated by and implicitly linked with tropical, extratropical, and polar atmospheric circulations ${ }^{30}$. The westerlies encompass extratropical, monsoon, and warm pools; the southerlies include subtropical and subpolar; and the easterlies comprise tropical and polar wave climate types ${ }^{30}$. This work identifies these global wave climates at the end of century using the RCP2.6 and RCP8.5 scenarios and analyses their differences with historical conditions. In the RCP2.6 scenario, global temperature rises up to $\sim 2^{\circ} \mathrm{C}$ above pre-industrial levels by the end-of-century, while the RCP8.5 scenario rises up to $\sim 4^{\circ} \mathrm{C}$. The actual temperatures reached of each RCP can vary depending on the Shared Socioeconomic Pathways ${ }^{33}$, we utilize the two pathways here as lower and upper bounds of potential warming. The global wave climate projections (Shimura and Mori, 2020) ${ }^{34}$ dataset used consists of hourly output at $0.5^{\circ}$ spatial resolution; in addition, the projections were generated using the spectral wave model WAVEWATCH III ${ }^{35}$ and forced with atmospheric winds from the Japanese Meteorological Research Institute's high-resolution (20 km horizontal) atmospheric general circulation model (MRI-AGCM). Each time slice covers a 25-year period, from 1979 to 2003 for the historical conditions and from 2075 to 2099 for the RCP2.6 and RCP8.5 scenarios.

The wave climates were first classified for historical conditions (1979-2003) by applying a dynamic $k$ means clustering technique to multivariate data-normalized monthly average wave power $\left(P_{w}\right)$ and wave direction ( $\left.\mathrm{Dir}_{\mathrm{m}}\right)$-using the method described in the supporting materials of Odériz et al. $(2021)^{30}$. The clustering technique identified three major wave climates-the easterlies, westerlies, and southerliesand are shown in Figs. 1a-c. Each cluster centroid, defined as the arithmetic mean of each variables assigned to each cluster, had similar values (1979-2003) to those obtained in Odériz et al. $(2021)^{30}$, 
which used the ERA5 (1979-2018 and 1979-2017) and JRA-55 (1979-2017) reanalysis datasets. This classification was repeated for the RCP2.6 and RCP8.5 scenarios (2075-2099) using the calculated centroids from the historical conditions (1979-2003) rather than generating new ones. Here, we will focus on the RCP 8.5 scenario but more details of the RCP2.6 scenario can be found in the supplementary information (Figures SI-6-11, 14, 16, 19-23).

\section{Changes in wave power}

Since the wave climates are linked implicitly to their origin in the planetary wind systems, their temporal and spatial shifts are related to changes in atmospheric circulation. Over the Arctic, polar atmospheric circulation is projected to intensify due to a lower pressure ${ }^{36}$ and increased positive phase of the Arctic Oscillation, leading to strengthened polar (up to $+30 \mathrm{~kW} / \mathrm{m}$ ), and subpolar (up to $+20 \mathrm{~kW} / \mathrm{m}$ ) wave power in the North Atlantic and North Pacific Oceans. These changes will affect the wave power reaching the coasts of Greenland and Russia (up to +20 and $\sim+10 \mathrm{~kW} / \mathrm{m}$, respectively).

Polar atmospheric circulation plays a key role in the planetary wind system ${ }^{36}$, and under lower pressure and an increasingly positive phase of the annular modes (Arctic Oscillation and Southern Annular Mode, SAM), more intense, poleward extratropical winds will be produced ${ }^{37,38}$. This phenomenon will intensify the extratropical wave climate in the high-latitudes of the North Atlantic and North Pacific Oceans $(\sim+10$ and $+25 \mathrm{~kW} / \mathrm{m})$, and in the Southern Ocean $(\sim+20 \mathrm{~kW} / \mathrm{m})$. On the other hand, a poleward displacement of the extratropical circulation will cause the extratropical wave power to weaken in mid-latitudes of the aforementioned regions ${ }^{39}$. In the Southern Ocean, the highest increases of wave power are projected to occur during JJA $(\sim+30 \mathrm{~kW} / \mathrm{m})$, due to the more positive trend projected for the SAM in this season and its impacts on the extratropical winds ${ }^{40}$. The subtropical wave climate also intensifies in the South Pacific. In the Indian and South Atlantic Oceans, the subtropical wave power will lessen in line with the weakening high-pressure belts in these regions ${ }^{41,42}$

Overall, the tropical wave power is projected to decrease $(\sim-5 \mathrm{~kW} / \mathrm{m})$ as a response to increasing greenhouse gases, causing a weakening in the east-west tropical circulation ${ }^{43,44}$. This wave climate, in the southern Caribbean Sea, is projected to increase (see Fig. $1 \mathrm{~m}$ and Figure SI 12b). In this region, the Caribbean Sea is getting warmer than the Atlantic Ocean and creating a strong pressure gradient ${ }^{38}$, which in turn, increases wind velocity ${ }^{45}$ and wave power. In the Indian Ocean, the monsoon wave power is expected to decrease by $20 \mathrm{~kW} / \mathrm{m}$ (see Fig. 1f, 1n). This coincides with weakened monsoon winds, caused by the Intertropical Convergence Zone (ITCZ) shifting toward the warmer Northern Hemisphere ${ }^{46}$.

On the whole, increases in total wave power will be concentrated in the high-latitudes-more so in the Southern Hemisphere (extratropical and subtropical wave climate types) than in the Northern Hemisphere (easterly polar and southerly subpolar wave climate types). In the Southern Hemisphere, all of the wave climates are projected to increase in wave power. In contrast, the tropical, extratropical in mid-latitudes, 
and subtropical wave climate types are projected to decrease on average in the Northern Hemisphere (see Figure SI-13).

\section{Changes in wave direction}

For the most part, the results show an anticlockwise rotation in annual mean wave direction in the highlatitude oceans and a clockwise rotation elsewhere (see Figure SI-3b), in line with Morim et al. (2019) ${ }^{8}$, except for the North Atlantic, and parts of the Pacific and Southern Oceans. In the Atlantic Ocean, the anticlockwise rotation of the tropical wave climate type is limited to the northern part only (except JJA) and stems from a northwest shift in the high-pressure system ${ }^{47,48}$. Furthermore, a clockwise rotation occurs in the south-western part of the same wave climate $\left(\sim+15^{\circ}, \mathrm{DJF}\right)$, which is forced by a southward displacement of the regional high-pressure system ${ }^{42}$ and is linked with the expanding tropics ${ }^{49}$.

In the Pacific Ocean, the mean wave direction in the tropical wave climate type rotates anticlockwise ( $\left.-20^{\circ}\right)$ in DJF, and clockwise in MAM and JJA $\left(\sim+15^{\circ}\right)$. In the North Pacific, the mean wave direction in the extratropical and subpolar wave climate types rotate clockwise in DJF and is forced by a southeastern displacement of the Aleutian Low ${ }^{48}$. During this same period (DJF), an increasing positive phase of the SAM will produce a poleward shift in the extratropical winds ${ }^{37,38}$, and therefore a clockwise rotation $\left(\sim+20^{\circ}\right)$ in the respective wave climate.

\section{Changes in area covered by each wave climate}

In general, the easterly and southerly (westerly) wave climates are projected to expand (shrink) in size annually in all basins except for the Southern Ocean (Fig. 3). The proportion of area covered annually by the easterlies is projected to increase by $2.5 \%$ globally and nearly $3.7 \%$ in the Pacific Ocean. A similar increase is projected to occur globally for the southerlies $(+2.3 \%)$, with the most significant expansion being in the Indian Ocean at $+4.5 \%$. The opposite trend is projected to occur for the westerlies, which is projected to shrink globally $(-1.4 \%)$, with $4.9 \%$ and $3.5 \%$ decreases occurring in the Indian and Pacific Oceans (respectively). There is, however, an exception in the Southern Ocean, where the proportion of area covered annually drops by almost $12 \%$ and $8.4 \%$ for the easterlies and southerlies (respectively) and expands by $22 \%$ for the westerlies. This is related to the poleward displacement of the extratropical atmospheric circulation ${ }^{39}$. On a seasonal and basin scale, the general patterns hold but there are some differences, see Supplementary Information.

\section{The transitional wave climate regions: continental and polar coasts}

As mentioned before, the dynamical wave climates are classified by mean wave direction and wave power. In that sense, an increase in the number of wave events approaching a coast will greatly affect its near-shore wave conditions. Hence, we classify the coasts in Figs. 4-6 using a priority scale, which is 
based on an increase in the occurrence frequency of any wave climate; the classifications are (Priority) I: 5-10\%, II: 10-15\%, III: 15-20\%, and IV: >20\%.

\section{Continental transitional wave climates}

Overall, regions identified as Priority III and IV tend to coincide with significant changes in wave power (see Figs. 4 and SI-17, 18). Some of the largest of these projected changes occur with the southerly wave climate, which will drive nearshore dynamics more frequently in the eastern Pacific (i.e., from Mexico to Chile), Southeast Atlantic (i.e., from Nigeria to Angola), and south and west of Australia during many of the seasons (e.g., MAM in Southeast Atlantic). In terms of changes, the southerly wave power is projected to increase upwards of $+2 \mathrm{~kW} / \mathrm{m}$ in the North Indian Ocean and $+8 \mathrm{~kW} / \mathrm{m}$ in Chile, Peru, Namibia, and South Africa. On the other hand, this same wave power is projected to decrease in the Northwest Atlantic and southwest of the basins. The easterly wave climate will dominate more in these regions and wave power is projected to increase upwards of $+2 \mathrm{~kW} / \mathrm{m}$ along much the eastern coast of the U.S.A, southeast of Africa (Kenya, Tanzania, Mozambique, and Madagascar), the southwest Pacific, and northwest of the Atlantic basins. As for the westerlies, the extratropical wave climate type will be less frequent in the midhigh latitudes of all ocean basins and will become more frequent in the northern polar region and near New Zealand due to the poleward displacement of the extratropical winds 37,38 . In some regions, seasonal variability will increase the bimodality of the wave climates. For instance, in Hawaii, the southerly wave climate will become more prevalent all year round, but the westerly and easterly wave climate will increase in frequency and wave power during DJF.

\section{Polar transitional wave climates}

Wave-ice interactions play an essential role in the Marginal Ice Zone (MIZ), and changes to sea ice melting patterns will impact the wave climate. For example, fetch and wave energy will increase in regions where broken sea ice has melted; likewise, wave development will become hampered in regions where blocks of floating ice have refrozen and dissipate wave energy ${ }^{50-52}$. In addition, summer and winter sea ice extents have declined over the past several decades, and the likelihood of storms residing in ice-free waters has increased, increasing the chances of extreme wave events occurring and thus increasing the overall wave power in the region ${ }^{50-52}$. This can further accelerate the decline of the sea ice extent and expose coastlines to rapid erosion ${ }^{53}$. High latitude waves in newly open regions may also act as an ecological driver by transporting new species and pollution, and altering the carbon cycle ${ }^{18,53,54}$. Incidentally, sea ice retreat will potentially increase economic opportunities, such as increasing transArctic vessel traffic (along the Northern Sea Route and North West Passage) and opening areas for fishing and mineral extraction ${ }^{55}$. In the case of the RCP8.5 scenario, sea ice retreat is critical (Figures SI19-23) for the MIZs in the Arctic and the Antarctic Oceans ${ }^{32}$; this is particularly true in the Arctic which is projected to be mostly ice-free. However, the results we show for the polar regions must be interpreted cautiously since the wave model setup used here is not coupled with a sea ice model to dynamically account for wave-ice interactions. 
It is particularly important to identify transitional wave climates for coastal erosion. In the Arctic circle, a sea-level rise of $0.3 \mathrm{~m}$ more than the average for the rest of the world is projected ${ }^{56}$. Indeed, an average coastal erosion of $0.5 \mathrm{~m} /$ year has already been reported in many parts of the area ${ }^{53}$. Additionally, most of the Arctic coastlines in Fig. 5 will be exposed more frequently to all of the wave climates-the subpolar and polar in particular. This combined with sea-level-rise and retreating ice will only exacerbate erosion further. The polar wave climate type will be more frequent along Greenland, Alaska, and parts of Russia, particularly during DJF and MAM. The extratropical wave climate type on the other hand, will be more frequent along parts of Canada and Russia during DJF and SON. However, the most striking change occurs with the subpolar wave climate type, which is projected to become more frequent along most of the Arctic Circle during DJF and MAM. The Siberian coast, which already has the highest detected rate of erosion for permafrost coastlines (above $3 \mathrm{~m} /$ year) ${ }^{53}$, will likely see further increases in erosion since the combined frequency of all three wave climates are projected to increase year-round: DJF and MAM from subpolar and polar, JJA from polar, and SON from subpolar and extratropical wave climate types.

Coastlines in the Antarctica will be affected differently. The largest increases in occurrence frequency of the wave climates are projected to occur along shorelines facing the Indian Ocean $\left(0^{\circ}-180^{\circ} \mathrm{E}\right)$; these are for polar during JJA, extratropical during DJF, and subpolar during JJA and SON. While coasts facing the Weddell Sea will be protected from westerlies by the Antarctica peninsula, they will be affected by easterlies and southerlies year-round. The Ross Sea will be also be affected by southerlies and easterlies for most of the year, with the exception of DJF, when more westerly wave events are projected reach its coasts. Changes in wave climate in the Antarctic Ocean will lead to changes in swell over the low latitudes of the Indian, Pacific, and Atlantic Oceans ${ }^{57}$. Therefore, wave climate changes in the Antarctic Ocean are not mostly confined to the region as with the Arctic Ocean.

\section{Conclusions}

Climate changes affects atmospheric circulation driving changes on current prevailing wave climates and the potential spatial and temporal differences of wave climates need to be assessed. In this paper, we have identified the major westerly, southerly, and easterly wave climate that are driven by planetary wind systems for the historical and end-of-century periods in the RCP2.6 and RCP8.5 scenarios. By comparing the two time periods, this study provides a comprehensive analysis of the spatial-temporal changes in future projections of wave climate under two RCP warming scenarios.

An increase in wave power will be most noticeable in the polar regions and in the Southern Hemisphere. Wave power in the extratropical wave climate type is projected to increase in high-latitudes and decrease in mid-latitudes due to an intensification and poleward displacement of the extratropical atmospheric circulation. In the Northern Hemisphere, the polar atmospheric circulation, with lower pressure system, is projected to increase wave power in the subpolar and polar wave climate types. The monsoon wave climate type is projected to weaken due to a northern displacement of the ITCZ. In general, wave power in the tropical wave climate type is projected to reduce by $20 \%$; however, it is projected to increase over the southern Caribbean Sea, due to an intensification of the regional wind systems. 
Particular attention has been paid to continental, sea ice, and permafrost coastlines because of the important role they play in industries and ecosystems. Regions of wave climate types with significant changes should serve as a large-scale roadmap on where to channel efforts to rebuild ocean ecosystems and improve resiliency ${ }^{24}$. In addition, the impacts of climate change will most likely be exacerbated in regions with transitioning wave climates, such as those with more frequent wave events. Therefore, these regions have been identified and prioritized by the occurrence frequency increase of the new prevailing wave climates. Overall, eastern coasts in each basin will be affected more by the southerly wave climate, while western coasts will be more affected by the easterly wave climate. Additionally, the extratropical wave climate type is projected to become more frequent in New Zealand, Chile, and South Africa, as the westerly wave climate intensifies and moves poleward. Since wave-ice interactions are not fully modeled in this study, analysis of the polar regions can be seen as a preliminary approach to define adaptation and conservancy strategies. Further work on this will be decisive in developing more accurate wave climate projections for the region ${ }^{58}$.

Our results show that the polar circulation plays a fundamental role in changes in the extratropical atmospheric circulation and also in the waves that are generated in high and mid-latitudes and propagate towards the tropics. Arctic amplification (warming near the poles) is occurring more rapidly than Antarctic amplification ${ }^{36}$, but the latter will have important implications for wave climates in the Southern Hemisphere and for eastern coasts in each basin. This pan-hemispheric asymmetry in the atmospheric system could be critical in the climate change adaptation timeline that countries face. This is especially true for coasts that face wave climate bimodality originating in both hemispheres, as in the East Pacific.

This work (i) improves the understanding of cause and effect between the atmospheric system and ocean waves, (ii) identifies transitional wave climate regions in future climate change scenarios, and (iii) offers a more precise classification of regional wave climate that will assist in developing roadmaps for coastal risk adaptation. To our knowledge, this is the first wave climate projection that includes analyses on circumpolar coastlines.

\section{Declarations}

\section{Acknowledgements}

Thanks to all at Nobuhito's lab for the warm welcome during my stay in Japan. This work was possible thanks to the financial support of DPRI research funds; JSPS KAKENHI and Integrated Research Program for Advancing Climate Models (TOUGOU Program: JPMXD0717935498) supported by MEXT of Japan; and Fondo CONACYT-SENER/Sustentabilidad Energética through the Centro Mexicano de Inovación en Energías del Océano (CEMIE-Océano), grant number 249795.

\section{References}


1. Toimil, A. et al. Climate change-driven coastal erosion modelling in temperate sandy beaches: Methods and uncertainty treatment. Earth-Science Rev. 202, 103110 (2020).

2. Vousdoukas, M. I. et al. Sandy coastlines under threat of erosion. Nat. Clim. Chang. 10, 260-263 (2020).

3. Ranasinghe, R. Assessing climate change impacts on open sandy coasts: A review. Earth-Science Rev. 160, 320-332 (2016).

4. Izaguirre, C., Losada, I. J., Camus, P., Vigh, J. L. \& Stenek, V. Climate change risk to global port operations. Nat. Clim. Chang. (2020). doi:10.1038/s41558-020-00937-z

5. Hemer, M. A., Fan, Y., Mori, N., Semedo, A. \& Wang, X. L. Projected changes in wave climate from a multi-model ensemble. Nat. Clim. Chang. 3, 471-476 (2013).

6. Hemer, M. A., Wang, X. L., Weisssse, R. \& Swail, V. R. Advancing wind-waves climate science: The COWCLIP project. Bull. Am. Meteorol. Soc. 93, 791-796 (2012).

7. Meucci, A., Young, I. R., Hemer, M., Kirezci, E. \& Ranasinghe, R. Projected 21st century changes in extreme wind-wave events. Sci. Adv. 6, eaaz7295 (2020).

8. Morim, J. et al. Robustness and uncertainties in global multivariate wind-wave climate projections. Nat. Clim. Chang. 9, 711-718 (2019).

9. Morim, J., Hemer, M., Cartwright, N., Strauss, D. \& Andutta, F. On the concordance of 21 st century wind-wave climate projections. Glob. Planet. Change 167, 160-171 (2018).

10. Reguero, B. G., Losada, I. J. \& Méndez, F. J. A recent increase in global wave power as a consequence of oceanic warming. Nat. Commun. 10,1-14 (2019).

11. Lemos, G. et al. Mid-twenty-first century global wave climate projections: Results from a dynamic CMIP5 based ensemble. Glob. Planet. Change 172, 69-87 (2019).

12. Semedo, A. et al. Projection of Global Wave Climate Change toward the End of the Twenty-First Century. J. Clim. 26, 8269-8288

13. Mori, N., Shimura, T., Yasuda, T. \& Mase, H. Multi-model climate projections of ocean surface variables under different climate scenarios-Future change of waves, sea level and wind. Ocean Eng. 71, 122-129 (2013).

14. Shimura, T., Mori, N. \& Hemer, M. A. Projection of tropical cyclone-generated extreme wave climate based on CMIP5 multi-model ensemble in the Western North Pacific. Clim. Dyn. 49, 1449-1462 (2017).

15. Mentaschi, L., Vousdoukas, M. I., Voukouvalas, E., Dosio, A. \& Feyen, L. Global changes of extreme coastal wave energy fluxes triggered by intensified teleconnection patterns. Geophys. Res. Lett. 44, 2416- 
2426 (2017).

16. Melet, A. et al. Contribution of Wave Setup to Projected Coastal Sea Level Changes. J. Geophys. Res. Ocean. 125, e2020JC016078 (2020).

17. Melet, A., Meyssignac, B., Almar, R. \& Le Cozannet, G. Under-estimated wave contribution to coastal sea-level rise. Nat. Clim. Chang. 8, 234-239 (2018).

18. Fraser, C. I. et al. Antarctica's ecological isolation will be broken by storm-driven dispersal and warming. Nat. Clim. Chang. 8, 704-708 (2018).

19. Kusumoto, B. et al. Global distribution of coral diversity: Biodiversity knowledge gradients related to spatial resolution. Ecol. Res. 35, 315-326 (2020).

20. Short, F., Carruthers, T., Dennison, W. \& Waycott, M. Global seagrass distribution and diversity: A bioregional model. J. Exp. Mar. Bio. Ecol. 350, 3-20 (2007).

21. Giri, C. et al. Status and distribution of mangrove forests of the world using earth observation satellite data. Glob. Ecol. Biogeogr. 20, 154-159 (2011).

22. Jonathan, S. A global map of mangrove forest soil carbon at $30 \mathrm{~m}$ spatial resolution. Environ. Res. Lett. 13, (2018).

23. Ribó, M., Goodwin, I. D., O'Brien, P. \& Mortlock, T. Shelf sand supply determined by glacial-age sealevel modes, submerged coastlines and wave climate. Sci. Rep. 10, 462 (2020).

24. Duarte, C. M. et al. Rebuilding marine life. Nature 580, 39-51 (2020).

25. Lobeto, H., Menendez, M. \& Losada, I. J. Future behavior of wind wave extremes due to climate change. Sci. Rep. 11, 7869 (2021).

26. Morim, J. et al. Global-scale changes to extreme ocean wave events due to anthropogenic warming. Environ. Res. Lett. 16, 74056 (2021).

27. Echevarria, E. R., Hemer, M. A. \& Holbrook, N. J. Seasonal Variability of the Global Spectral Wind Wave Climate. J. Geophys. Res. Ocean. 124, 2924-2939 (2019).

28. Jiang, H. Wave Climate Patterns from Spatial Tracking of Global Long-Term Ocean Wave Spectra. J. Clim. 33, 3381-3393 (2020).

29. Jiang, H. \& Mu, L. Wave Climate from Spectra and Its Connections with Local and Remote Wind Climate. J. Phys. Oceanogr. 49, 543-559 (2019).

30. Odériz, I. et al. Natural Variability and Warming Signals in Global Ocean Wave Climates. Geophys. Res. Lett. n/a, e2021GL093622 (2021). 
31. Paula Camus, Fernando j. Mendez, Raul Medina, A. S. C. Analysis of clustering and selection algorithms for the study of multivariate wave climate. Coast. Eng. 58, 453-462 (2011).

32. Pörtner, H.-O., D.C. Roberts, V. Masson-Delmotte, P. Zhai, M. Tignor, E. Poloczanska, K. Mintenbeck, A. A. \& M. Nicolai, A. Okem, J. Petzold, B. Rama, N. M. W. (eds. . IPCC Special Report on the Ocean and Cryosphere in a Changing Climate. (2019).

33. MassonDelmotte, V., P. Zhai, A. Pirani, S. L. Connors, C. Péan, S. Berger, N. Caud, Y. Chen, L. Goldfarb, M. I. Gomis, M. Huang, K. Leitzell, E. Lonnoy, J. B. R. Matthews, T. K. Maycock, T. Waterfield, O. Yelekçi, R. Y. and B. Z. (eds. . IPCC, 2021: Summary for Policymakers. In: Climate Change 2021: The Physical Science Basis. Contribution of Working Group I to the Sixth Assessment Report of the Intergovernmental Panel on Climate Change. (2021).

34. Shimura, T. \& Mori, N. FUTURE CHANGES IN SPECTRAL WAVE CLIMATE AROUND JAPAN UNDER GLOBAL WARMING. Coast. Eng. Proc. (2020). doi:10.9753/icce.v36v.waves.10

35. Tolman, H. et al. User manual and system documentation of WAVEWATCH III (R) version 5.16. (2016).

36. Screen, J. A., Bracegirdle, T. J. \& Simmonds, I. Polar Climate Change as Manifest in Atmospheric Circulation. Curr. Clim. Chang. Reports 4, 383-395 (2018).

37. Miller, R. L., Schmidt, G. A. \& Shindell, D. T. Forced annular variations in the 20th century Intergovernmental Panel on Climate Change Fourth Assessment Report models. J. Geophys. Res. Atmos. 111, (2006).

38. Nazarenko, L. et al. Future climate change under RCP emission scenarios with GISS ModelE2. J. Adv. Model. Earth Syst. 7, 244-267 (2015).

39. Chen, G., Lu, J. \& Frierson, D. M. W. Phase Speed Spectra and the Latitude of Surface Westerlies: Interannual Variability and Global Warming Trend. J. Clim. 21, 5942-5959 (2008).

40. Lim, E.-P. et al. The impact of the Southern Annular Mode on future changes in Southern Hemisphere rainfall. Geophys. Res. Lett. 43, 7160-7167 (2016).

41. Cherchi, A. et al. The Response of Subtropical Highs to Climate Change. Curr. Clim. Chang. Reports 4, 371-382 (2018).

42. He, C., Wu, B., Zou, L. \& Zhou, T. Responses of the Summertime Subtropical Anticyclones to Global Warming. J. Clim. 30, 6465-6479 (2017).

43. Lu, J., Deser, C. \& Reichler, T. Cause of the widening of the tropical belt since 1958. Geophys. Res. Lett. 36, (2009). 
44. Held, I. M. \& Soden, B. J. Robust Responses of the Hydrological Cycle to Global Warming. J. Clim. $19,5686-5699$

45. Costoya, X., deCastro, M., Santos, F., Sousa, M. C. \& Gómez-Gesteira, M. Projections of wind energy resources in the Caribbean for the 21 st century. Energy 178, 356-367 (2019).

46. Seth, A. et al. Monsoon Responses to Climate Changes-Connecting Past, Present and Future. Curr. Clim. Chang. Reports 5, 63-79 (2019).

47. Shaw, T. A. \& Voigt, A. Tug of war on summertime circulation between radiative forcing and sea surface warming. Nat. Geosci. 8, 560-566 (2015).

48. Choi, J., Lu, J., Son, S.-W., Frierson, D. M. W. \& Yoon, J.-H. Uncertainty in future projections of the North Pacific subtropical high and its implication for California winter precipitation change. J. Geophys. Res. Atmos. 121, 795-806 (2016).

49. Lucas, C., Timbal, B. \& Nguyen, H. The expanding tropics: A critical assessment of the observational and modeling studies. Wiley Interdiscip. Rev. Clim. Chang. 5, 89-112 (2014).

50. Liu, Q., Babanin, A. V, Zieger, S., Young, I. R. \& Guan, C. Wind and Wave Climate in the Arctic Ocean as Observed by Altimeters. J. Clim. 29, 7957-7975 (2016).

51. Rogers, W. E., Posey, P. G., Li, L. \& Allard, R. Forecasting and Hindcasting Waves In and Near the Marginal Ice Zone: Wave Modeling and the ONR Sea State Field Experiment. in (2018).

52. Thomson, J. \& Rogers, W. E. Swell and sea in the emerging Arctic Ocean. Geophys. Res. Lett. 41, 3136-3140 (2014).

53. Lantuit, H. et al. The Arctic Coastal Dynamics Database: A New Classification Scheme and Statistics on Arctic Permafrost Coastlines. Estuaries and Coasts 35, 383-400 (2012).

54. Shakhova, N. et al. Ebullition and storm-induced methane release from the East Siberian Arctic Shelf. Nat. Geosci. 7, 64-70 (2014).

55. EBINGER, C. K. \& ZAMBETAKIS, E. The geopolitics of Arctic melt. Int. Aff. 85, 1215-1232 (2009).

56. Cazenave, A. \& Cozannet, G. Le. Sea level rise and its coastal impacts. Earth's Futur. 2, 15-34 (2014).

57. Lemos, G., Semedo, A., Hemer, M., Menendez, M. \& Miranda, P. M. A. Remote climate change propagation across the oceans-the directional swell signature. Environ. Res. Lett. 16, 64080 (2021).

58. Babanin, A. V et al. Waves and Swells in High Wind and Extreme Fetches, Measurements in the Southern Ocean. Front. Mar. Sci. 6, 361 (2019). 


\section{Data And Methods}

The wave climate projection ${ }^{34}$ was forced by atmospheric wind conditions from the Japanese Meteorological Research Institute-Atmospheric GCM (MRI-AGCM), and with sea ice concentrations from the COBE SST and CMIP5 ensemble datasets. The wave climate projections were generated using the spectral wave model WAVEWATCH III version $5.16^{35}$ with a $0.5^{\circ}$ spatial and hourly temporal resolution. The time range is 25 years, from 1979 to 2003, for the historical conditions, and from 2075 to 2099 for the RCP2.6 and RCP8.5 scenarios. The wave power was computed for irregular waves, and both variables, wave power and mean wave direction, were monthly averaged.

The same method of dynamic clustering, as explained in Odériz et al. (2021), was applied for present conditions (1979-2003). For the two climate change scenarios, RCP2.6 and RCP8.5, the method was the same, but the centroids to cluster the data were predetermined, as those obtained for the present conditions (see Figure 7). The projection results were then grouped according to present conditions, which resulted in using the same clusters. Thus, instead of different climates, different projected characteristics are analysed.

The projected changes in mean wave direction are calculated only for those areas where the frequency of each wave climate is over $60 \%$. Unlike wave power, the mean wave direction cannot be divided by the complete temporal range-it is divided by the number of months in which the wave climate occurs. Otherwise, the physical magnitude of the direction loses its meaning. Therefore, in areas where the wave climate frequency is low, differences in mean wave direction are not representative for mid to long terms.

The seasonal averages of the wave climate variables were calculated using the following seasons: December, January, February (DJF); March, April, and May (MAM); June, July, and August (JJA); and September, October, and November (SON).

\section{Figures}




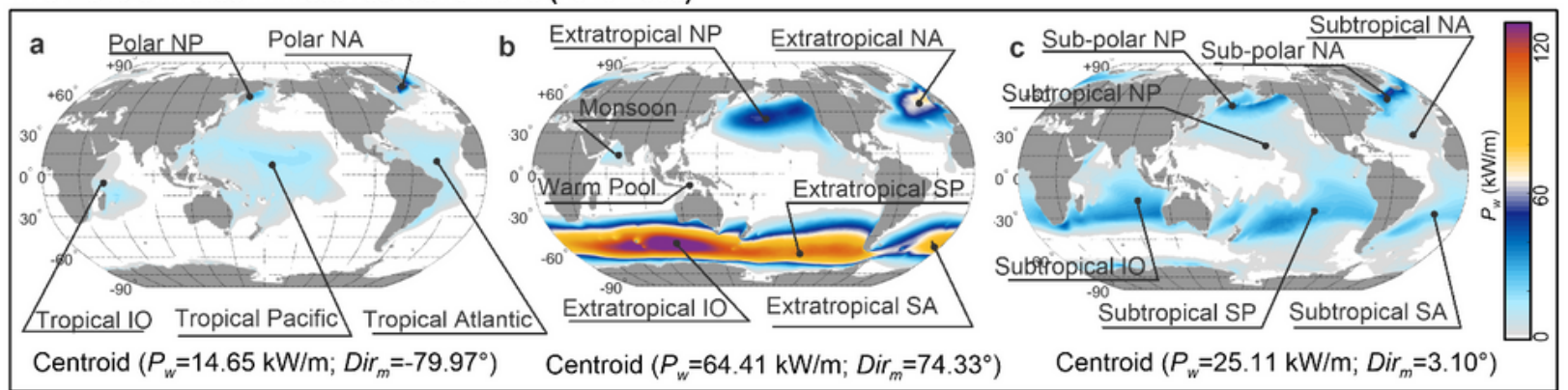

Differences in wave power between RCP8.5 (2075-2099) and historical conditions (1979-2003)
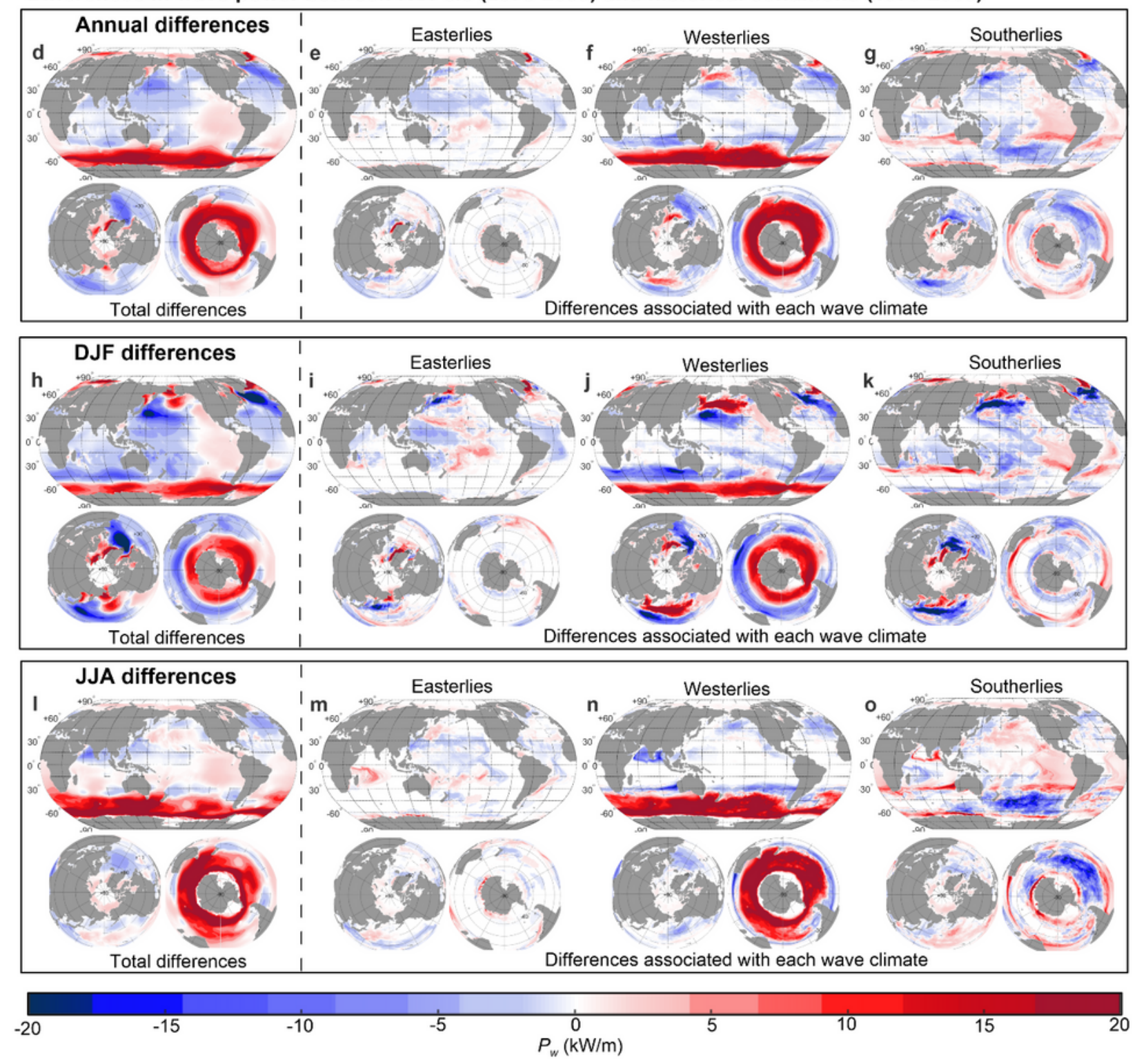

\section{Figure 1}

Annual average wave power (1979-2003) for the (a) easterly, (b) westerly, and (c) southerly wave climates. Differences in wave power between the RCP8.5 scenario and historical conditions for the $(d, h, l)$ total, and associated $(e, i, m)$ easterly, $(f, j, n)$ westerly, and $(g, k, o)$ southerly wave climates, during $(d-g)$ annual, (h-k) DJF, and (l-o) JJA periods. 
Difference in mean wave direction between RCP 8.5 (2075-2099) and Present conditions(1979-2003)
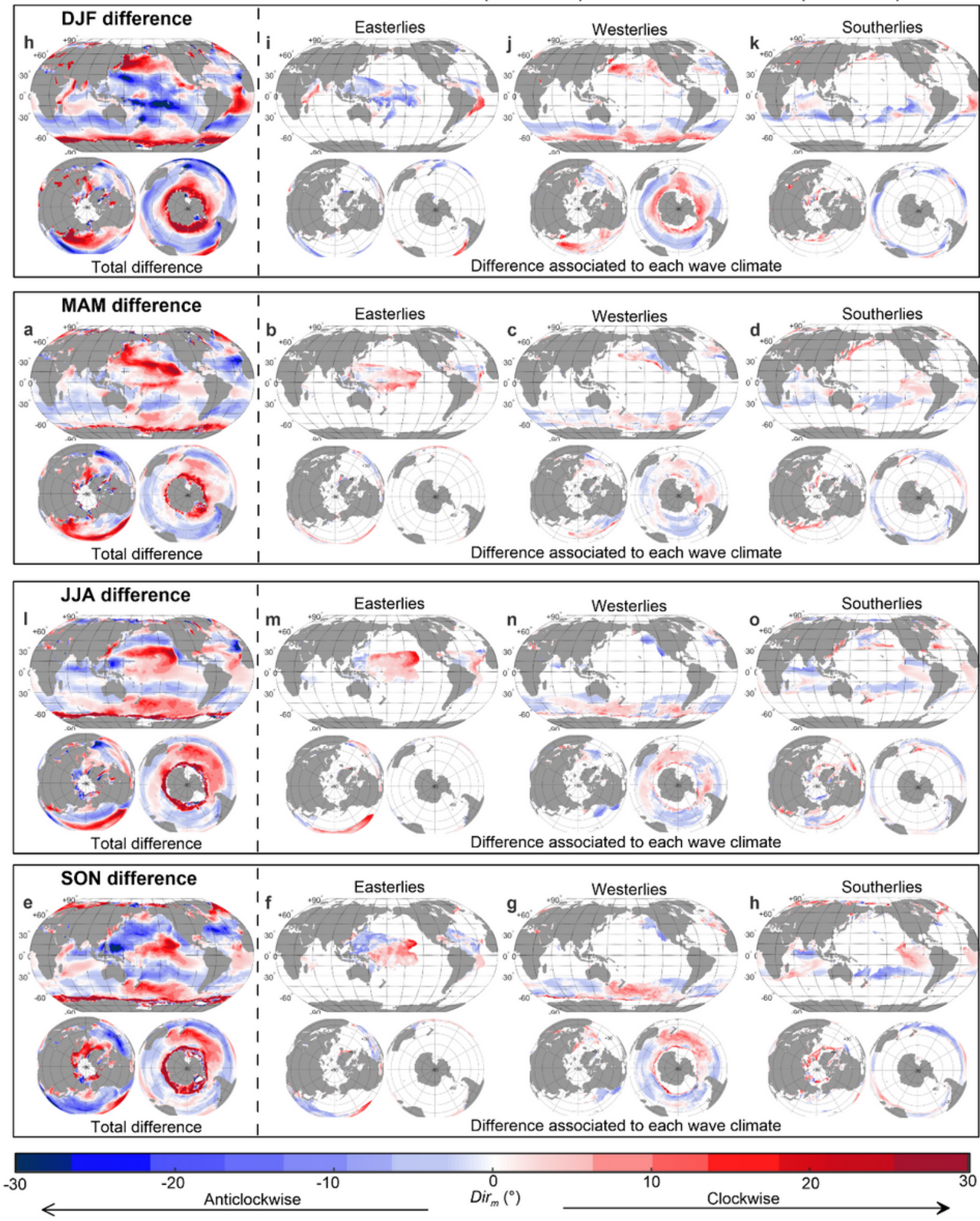

\section{Figure 2}

Differences in mean wave direction between the RCP8.5 scenario and historical conditions for the (a, e, i, m) total, and associated (b, f, j, n) easterly, $(c, g, k, o)$ westerly, and (d, h, I, p) southerly wave climates, during $(a-d) D J F,(e-h)$ MAM, ( $i-l) J J A$, and $(m-p)$ SON seasons. 


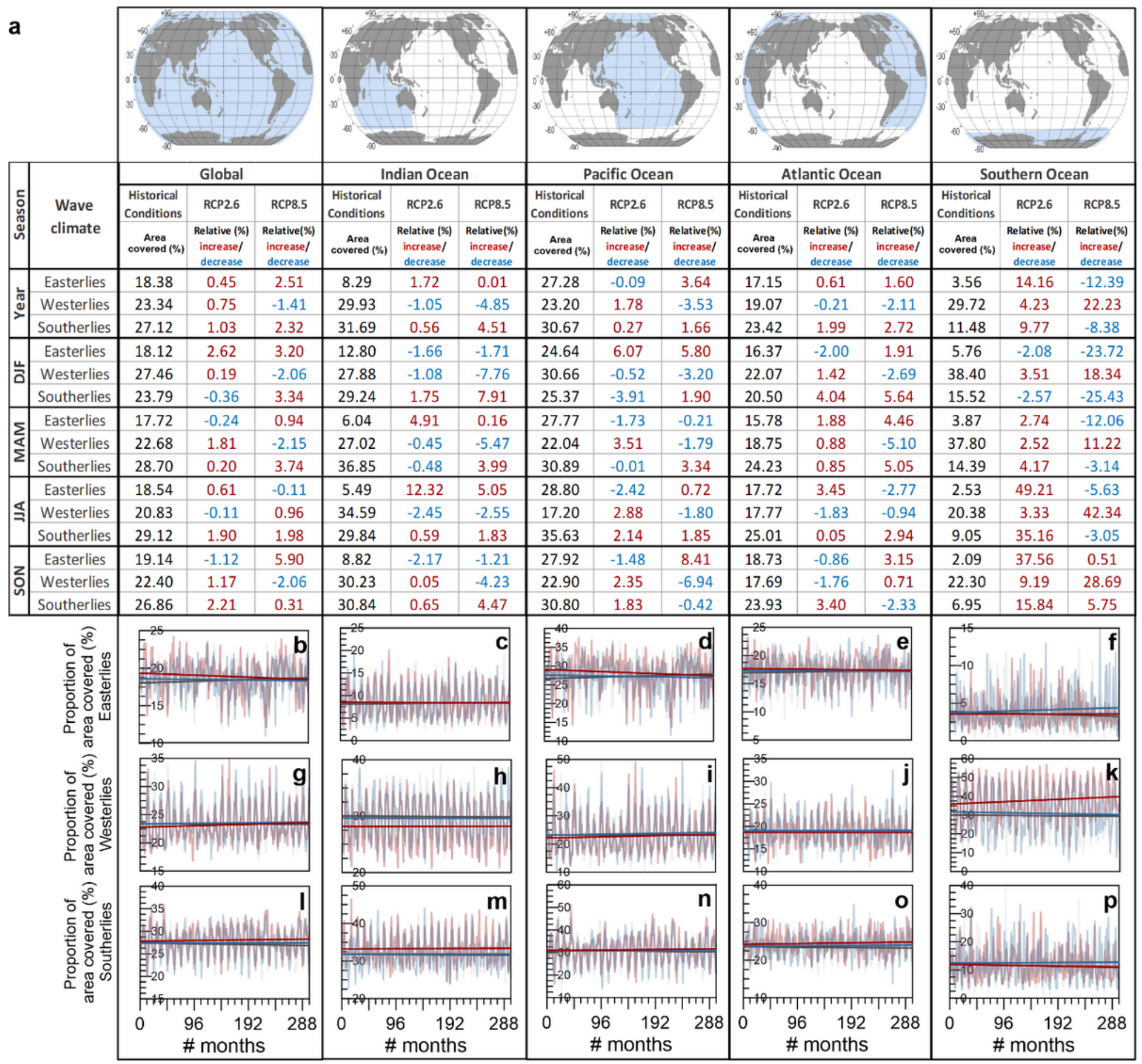

Time series of the area covered by each wave climate (\%)

Historical Conditions

RCP2.6

RCP8.5

\section{Figure 3}

a) Mean wave climate extension (area covered; \%) by basin during historical conditions, with relative differences (\%) between future scenarios. Time series of extension of $(b-f)$ easterly, $(g-k)$ westerly, and $(I-m)$ and southerly wave climates, for global region (b, g, I), Indian (c, h, m), Pacific (d, i, n), Atlantic (e, j, $o)$, and Southern Oceans ( $f, k, p)$. 
a Annual average-easterly wave climates

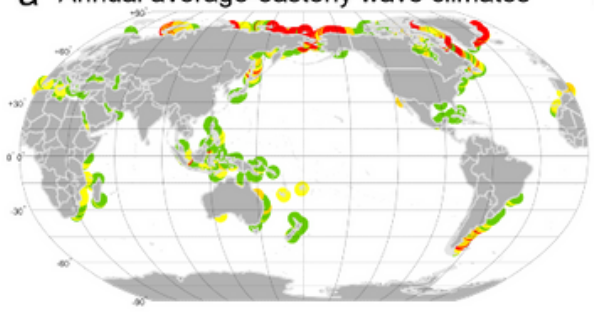

d DJF average-easterly wave climates e

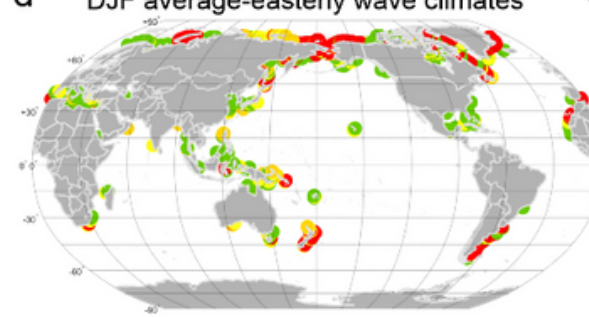

g MAM average-easterly wave climates

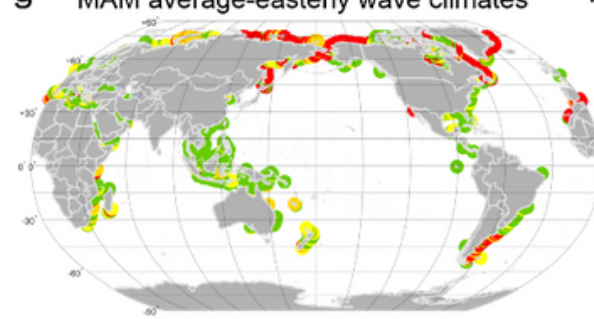

j JJA average-easterly wave climates k

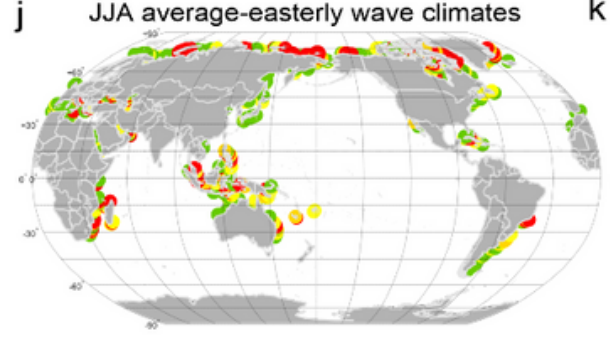

- SON average-easterly wave climates $p$

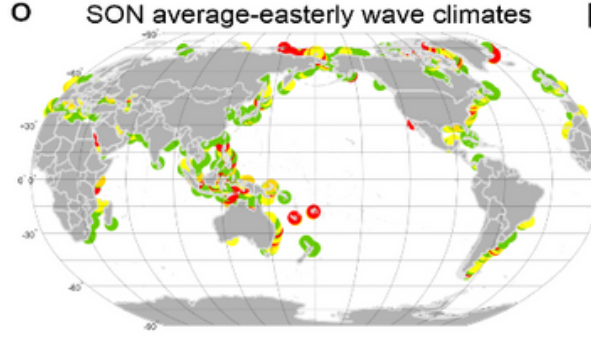

\section{Priority I} $5-10 \%$ b Annual average-westerly wave climates

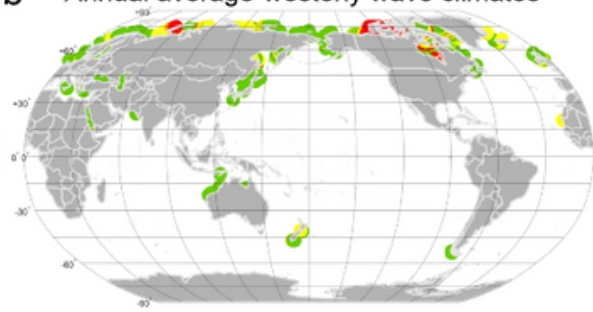

e DJF average-westerly wave climates f

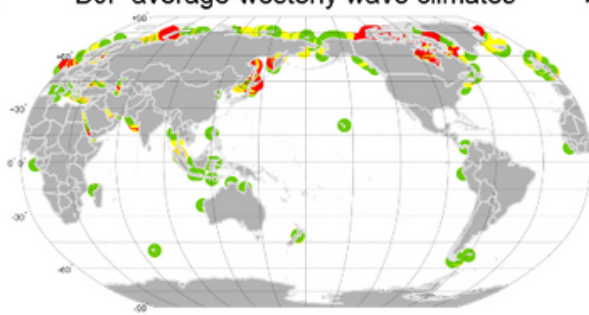

h MAM average-westerly wave climates i

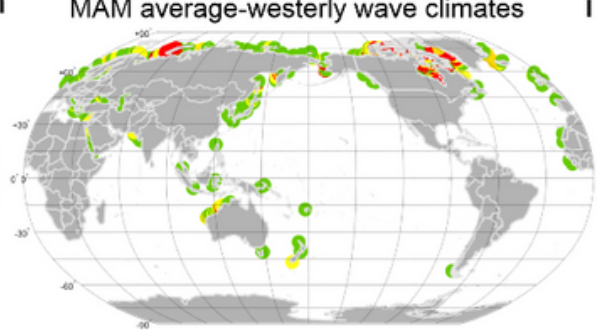

JJA average-westerly wave climates I

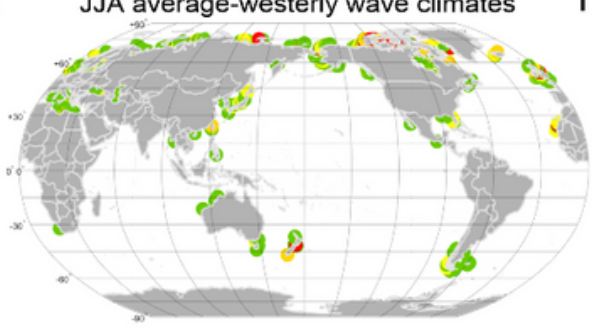

JJA average-southerly wave climates

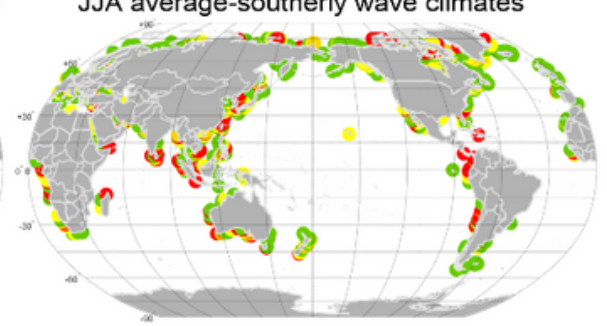

C Annual average-southerly wave climates

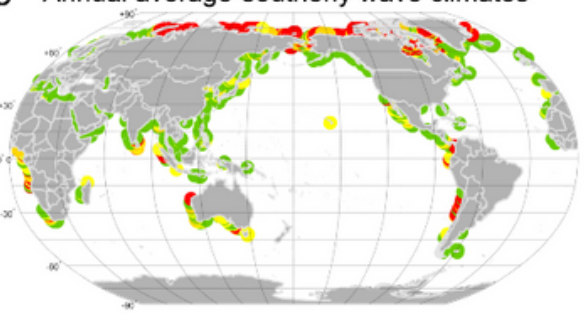

DJF average-southerly wave climates

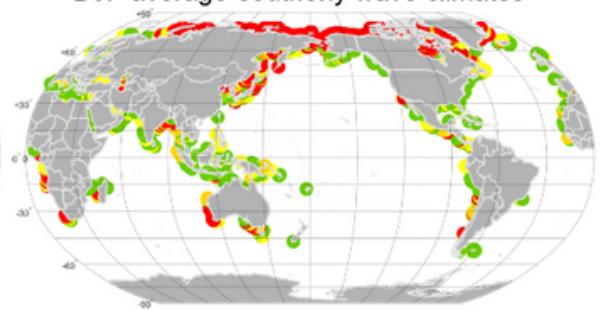

MAM average-southerly wave climates

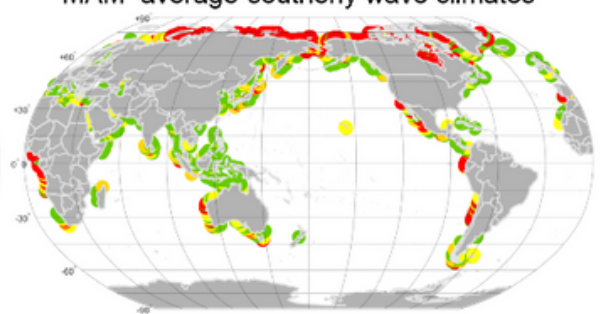

SON average-westerly wave climates

q SON average-southerly wave climates
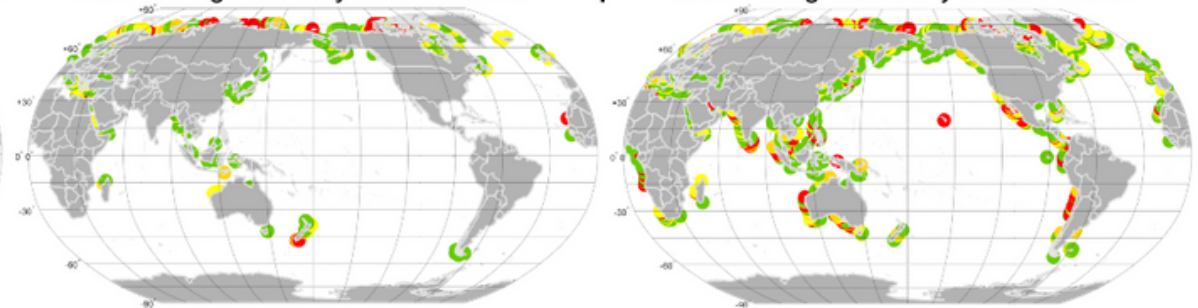

Priority III

$>20 \%$

$15-20 \%$

Increase in frequency of wave climates (\%)

under RCP8.5 scenario(2075-2099)

\section{Figure 4}

Transitional regions along continental coasts in the RCP8.5 scenario for the $(a, d, g, j, 0)$ easterly, $(b, e, h, k$, p) westerly, and (c, f, i, I, q) southerly wave climates, during (a-c) annual, (d-f) DJF, (g-i) MAM, (j-I) JJA, and $(0-q)$ SON periods. 
DJF average

easterly wave climates

Arctic coastlines

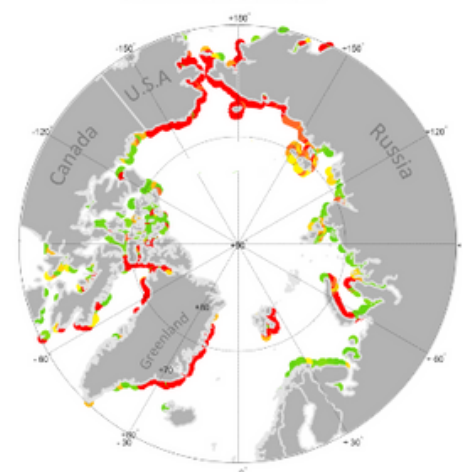

e

DJF average westerly wave climates Arctic coastlines

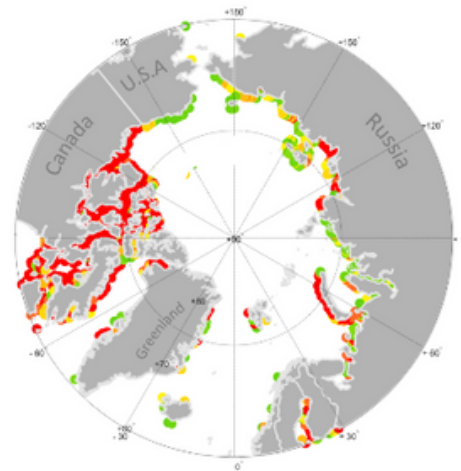

i

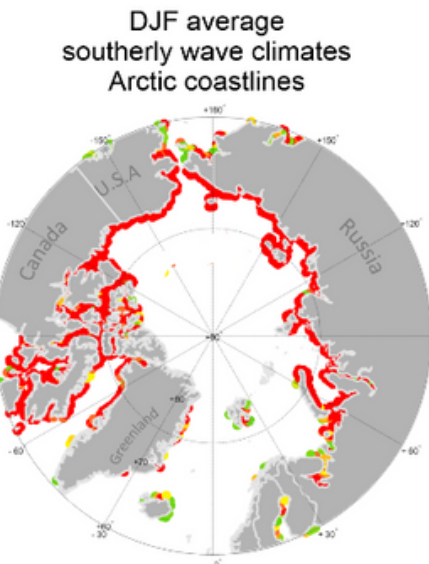

b

MAM average easterly wave climates Arctic coastlines

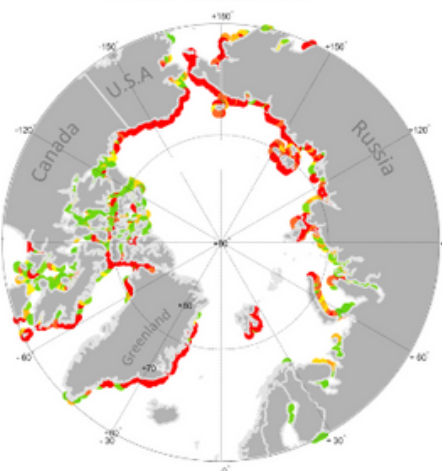

f

MAM average westerly wave climates Arctic coastlines

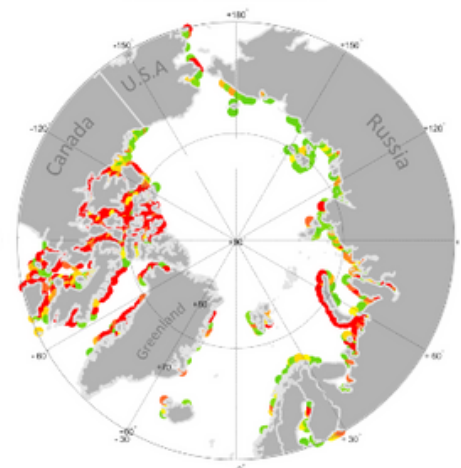

j

MAM average southerly wave climates Arctic coastlines

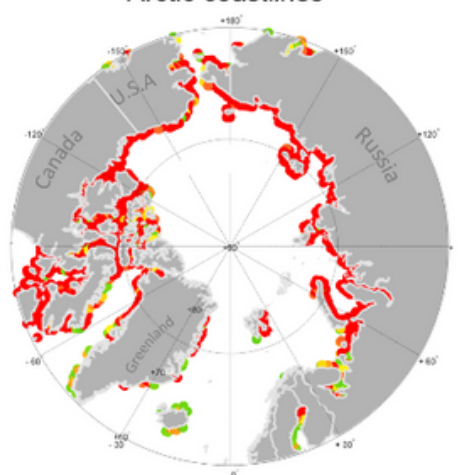

C

JJA average

easterly wave climates

Arctic coastlines

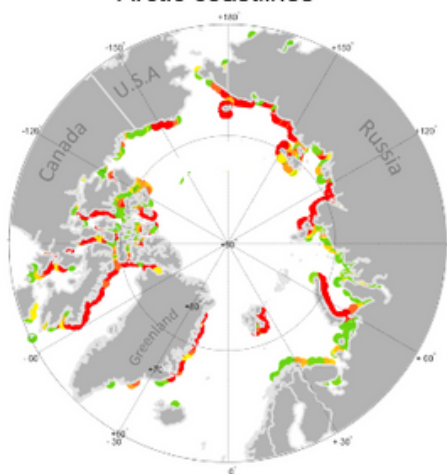

g

JJA average westerly wave climates Arctic coastlines

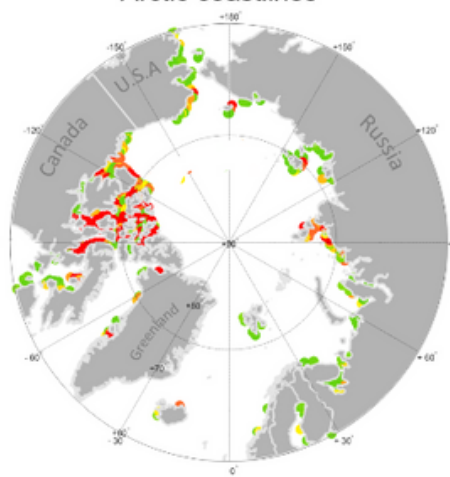

k

JJA average southerly wave climates Arctic coastlines

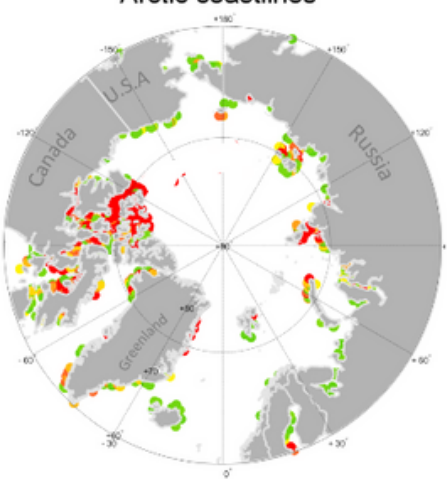

d

SON average easterly wave climates

Arctic coastlines

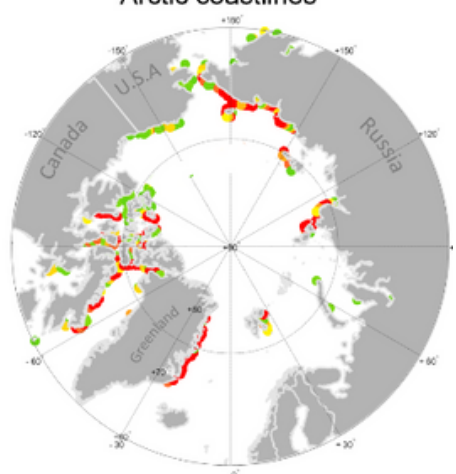

\section{h SON average westerly wave climates} Arctic coastlines

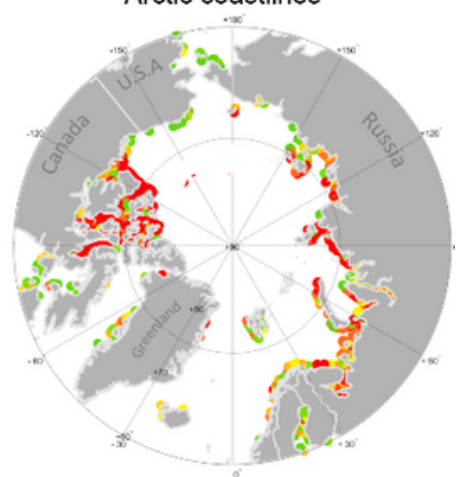

$$
\begin{gathered}
\text { SON average } \\
\text { southerly wave climates } \\
\text { Arctic coastlines }
\end{gathered}
$$

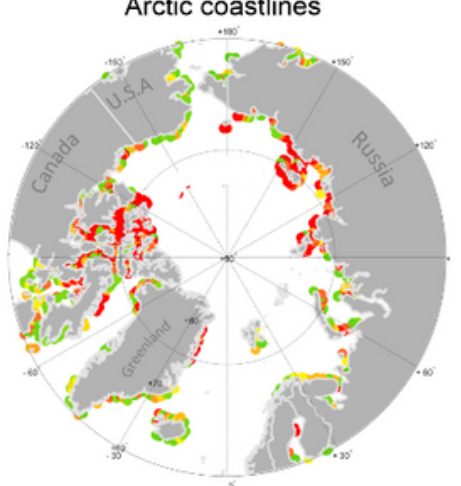

\section{Priority | 5-10\%}

Priority II $10-15 \%$

Increase in $\mathrm{f}$ under RCP8.5 scenario(2075-2099)

\section{Figure 5}

Transitional regions along Arctic coasts in the RCP8.5 scenario for the (a-d) easterly, $(e-f)$ westerly, and (i-l) southerly wave climates, during (a, e, i) DJF, (b, f, h) MAM, (c, g, k) JJA, and (d, h, l) SON seasons. 

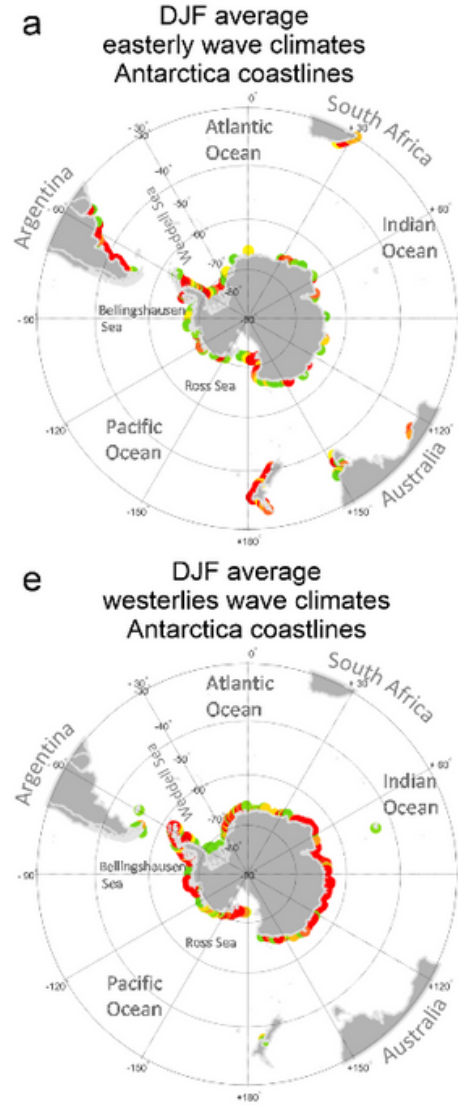

i

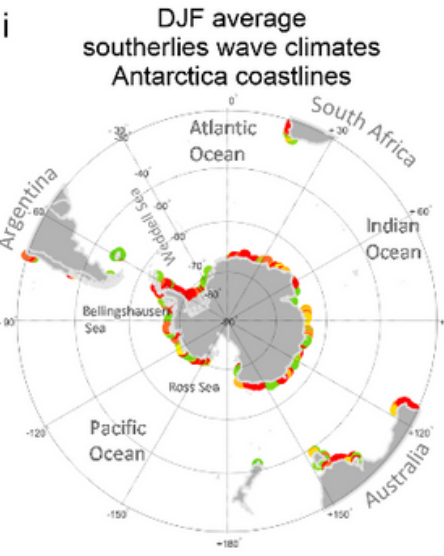

\section{Priority I}

5-10\% b MAM average

easterly wave climates

Antarctica coastlines

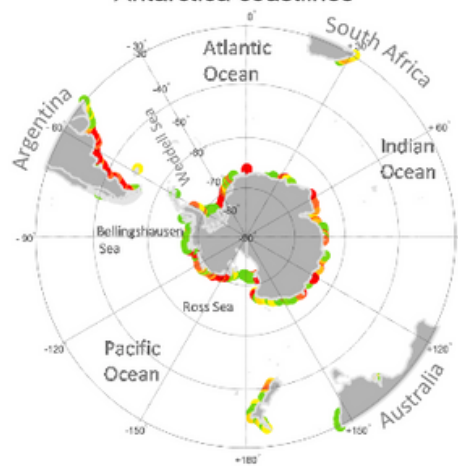

f MAM average

westerlies wave climates Antarctica coastlines

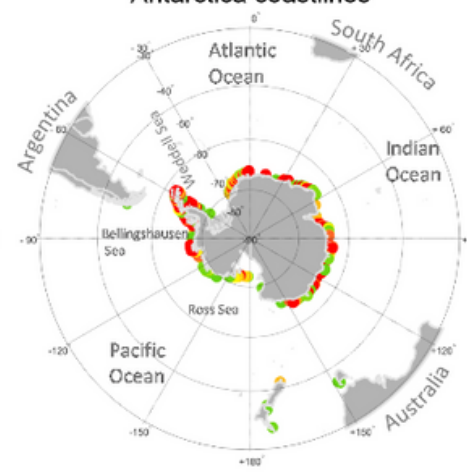

j MAM average southerlies wave climates Antarctica coastlines

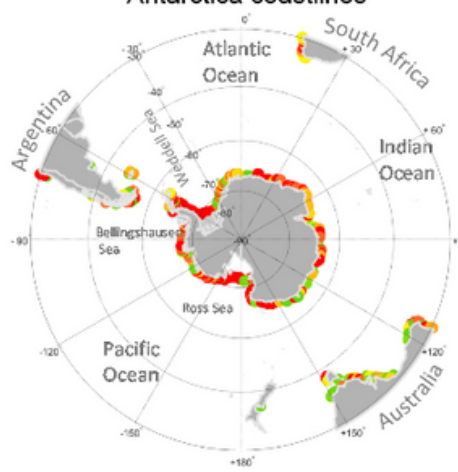

C

JJA average

easterly wave climates

Antarctica coastlines

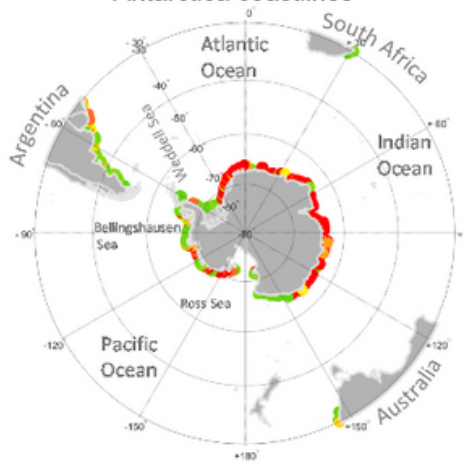

g JJA average

westerlies wave climates Antarctica coastlines

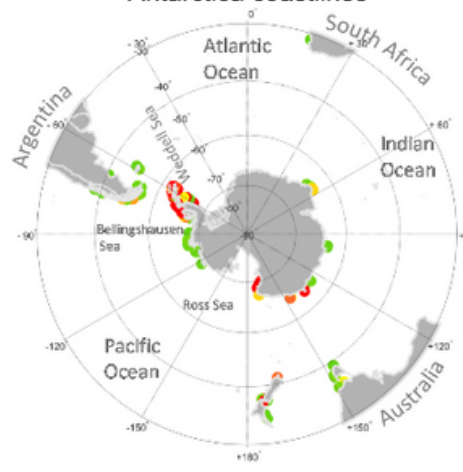

$\mathrm{k}$

JJA average

southerlies wave climates Antarctica coastlines

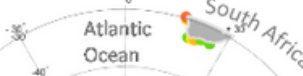

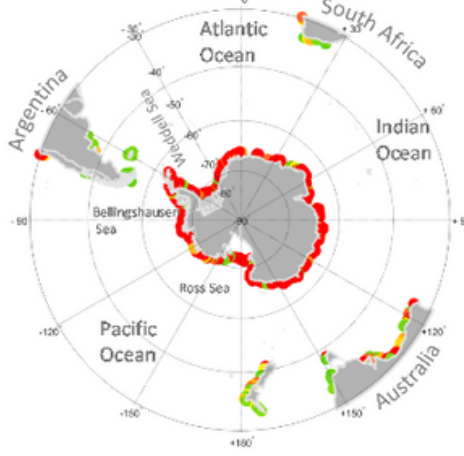

Priority III

$15-20 \%$

$>20 \%$
SON average easterly wave climates Antarctica coastlines

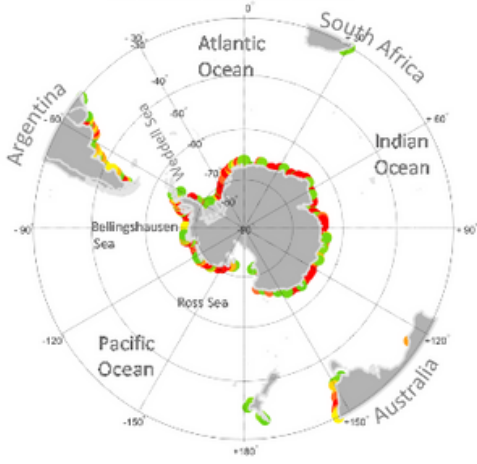

h SON average westerlies wave climates Antarctica coastlines

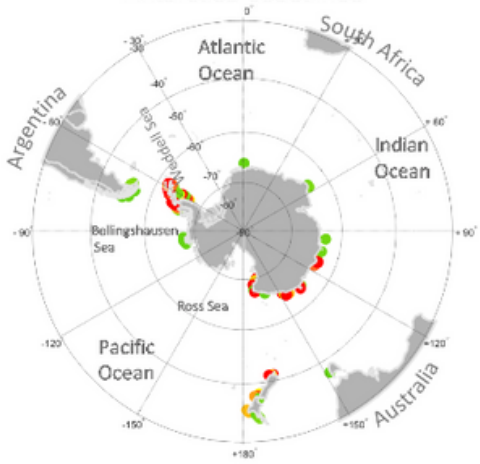

SON average

southerlies wave climates Antarctica coastlines

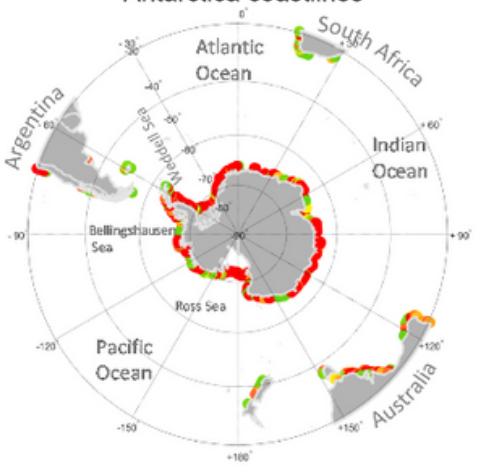

Priority II $10-15 \%$ Increase in frequency of wave climates (\%) under RCP8.5 scenario(2075-2099)

\section{Figure 6}

Transitional regions along Antarctic coasts in the RCP8.5 scenario for the (a-d) easterly, (e-f) westerly, and (i-l) southerly wave climates, during (a, e, i) DJF, (b, f, h) MAM, (c, g, k) JJA, and (d, h, l) SON seasons. 


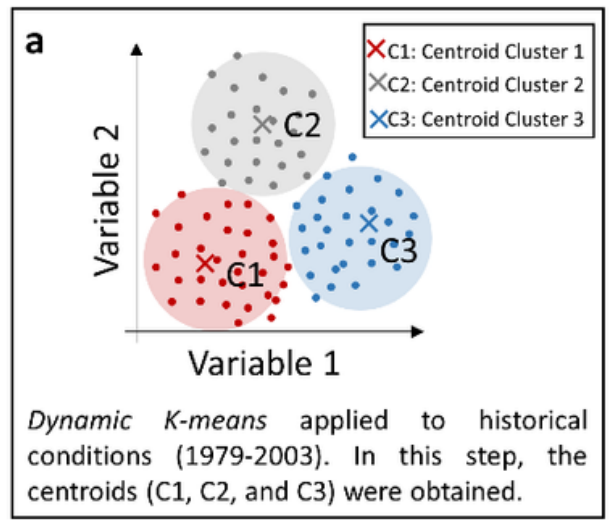

Historical conditions (1979-2003)

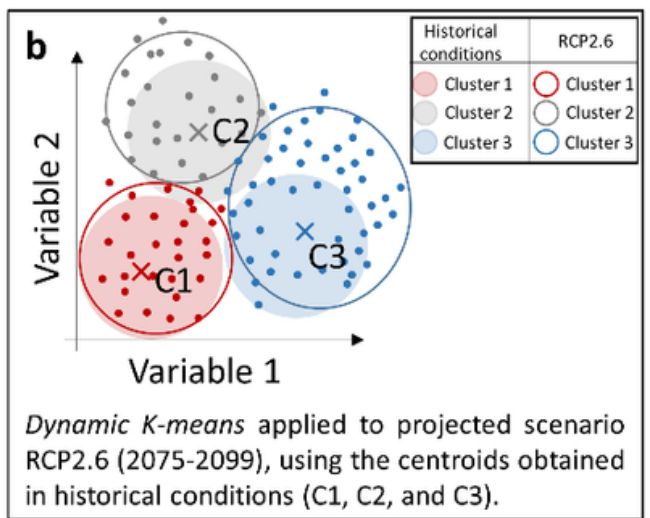

RCP2.6 (2075-2099)

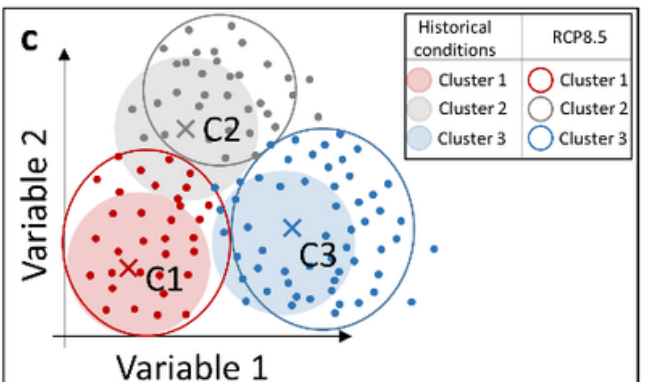

Dynamic $K$-means applied to projected scenario RCP8.5 (2075-2099), using the centroids obtained in historical conditions ( $11, \mathrm{C} 2$, and $\mathrm{C} 3$ ).

\section{Figure 7}

Conceptual explanation of the method applied for a) present conditions, b) projected scenarios RCP2.6 using the centroids calculated in (a), c) projected scenarios RCP8.5 using the centroids calculated in (a).

\section{Supplementary Files}

This is a list of supplementary files associated with this preprint. Click to download.

- SIforOderizetal2021NCC.v0.docx 